\title{
Nature's Radar
}

\author{
Tristan Gooley \\ (Independent Naturalist) \\ (E-mail: info@naturalnavigator.com)
}

The author uses a personal account of a short-handed small boat voyage, from the Orkney Islands into the Arctic Circle, to determine whether nature can help a navigator estimate their distance from land. As part of this exercise the author reinforces his argument (Gooley, 2010) that natural navigation clues add not only to safety and general awareness, but offer the navigator a richer experience than relying solely on electronic navigation. The main aim of this expedition and paper is to establish whether some of the traditional methods of navigation, used by Pacific Island and Viking navigators, can be of any value to the modern navigator. Recorded sightings of birds, cetaceans, fish, jellyfish, water behaviour and colour are used to support the author's findings. The paper also contains the author's reflections on the experience of undertaking a voyage of this kind and leads to one surprising conclusion.
KEY WORDS
1. Natural navigation.
2. North Atlantic.
3. Birds.
4. Vikings.

Submitted: 1 August 2012. Accepted: 6 September 2012. First published online: 31 October 2012.

1. INTRODUCTION. Electronic navigation systems have become the dominant tools of the modern navigator, but they have not removed the clues that nature offers. Necessity may be the mother of invention and there has been a long and continuing need for the ever-greater accuracy that is offered by radio and satellite navigation systems. This explains the sensible trend towards reliance on these systems, but it would be a shame if it led to an atrophying of the old skills. The best navigators make use of all the information available, whether it comes via a digital screen or by looking to the horizon. Information that comes via the nostril can be as valid as that which flows as electrons.

For inspiration in understanding the way it is possible to navigate using nature, the figure of Pytheas of Massalia serves us well (Cunliffe, 2002). Well over a thousand years before any form of compass arrived on the European navigation scene and more than two thousand years before the 1909 Nobel prizewinner Guglielmo Marconi was born in 1874 (Encyclopædia Britannica, 2012a), this ancient Greek astronomer and navigator made his way from the Mediterranean, far enough North to describe the midnight sun.

More recently, if not recent, Viking navigators demonstrated (Thirslund, 1997) the ability to travel great distances across the North Atlantic. Although not all their 
methods are fully understood, evidence that is woven into the sagas suggests a strong understanding of marine life, in addition to astronomical savvy.

Thanks to the work of researchers such as Lewis (1972), Lewis and George (1991) and George (2012), our understanding of the ability of Pacific Island navigators to use nature as a wayfinding system is surprisingly good. The question that this paper seeks to address is whether these techniques are of any value to the modern navigator.

We should not forget that the victors write history and we hear the stories of the navigators that made it, far fewer from those that did not. We know the name, 'Erik the Red', the legendary Viking who pioneered the route from Iceland to the new colony of Greenland (Encyclopædia Britannica, 2012b). He set off with 24 other boats. Almost half of these never made it to their destination and the names of the skippers of these boats are lost to us. There is no question of natural navigation methods being safer in isolation, but do they add anything at all?

The paper is set out as follows:

- Section 2 (The Plan) contains a summary of the planned voyage and reasons for the route chosen.

- Section 3 (The Method) provides a brief outline of our navigation and data collection methods and reasons for them.

- Section 4 (The Voyage) gives a more detailed outline and exposition of the voyage itself, putting the data and observations in context and hopefully giving the reader a deeper understanding of the exercise.

- Section 5 (The Birds) details the methods used, data collected and trends noted from bird sightings.

- Section 6 (The Clouds) gives a summary of pertinent and anomalous cloud sightings.

- Section 7 (The Water) gives a summary of the times when the water colour or behaviour could have been of navigational value.

- Section 8 (Flotsam, Seaweed and Jellyfish) gives a summary of the sightings and trends.

- Section 9 (Cetaceans) gives a summary of the sightings.

- Section 10 (The Surprise) explains one unintended consequence of our observations.

- Section 11 (Caveat) provides a cautionary note.

- Section 12 provides the Conclusions of the paper.

- Appendix A gives details of the observations and sighting made on the voyage.

2. THE PLAN. The plan was simple: to lead a sailing expedition from Kirkwall in the Orkney Islands into the Arctic Circle, with the sole aim of noting the natural clues to the proximity of land. The idea was to route via the Faroe Islands, without stopping, as this would give a good sample of rising and falling distances from land (see Figure 1). As the Orkney and Shetland Islands receded, in turn the Faroes and Iceland would draw nearer. The boat chosen was my own Contessa 32 'Goldeneye', and it was to be a short-handed sail, the only other crewmember being my Mate, John Pahl. 


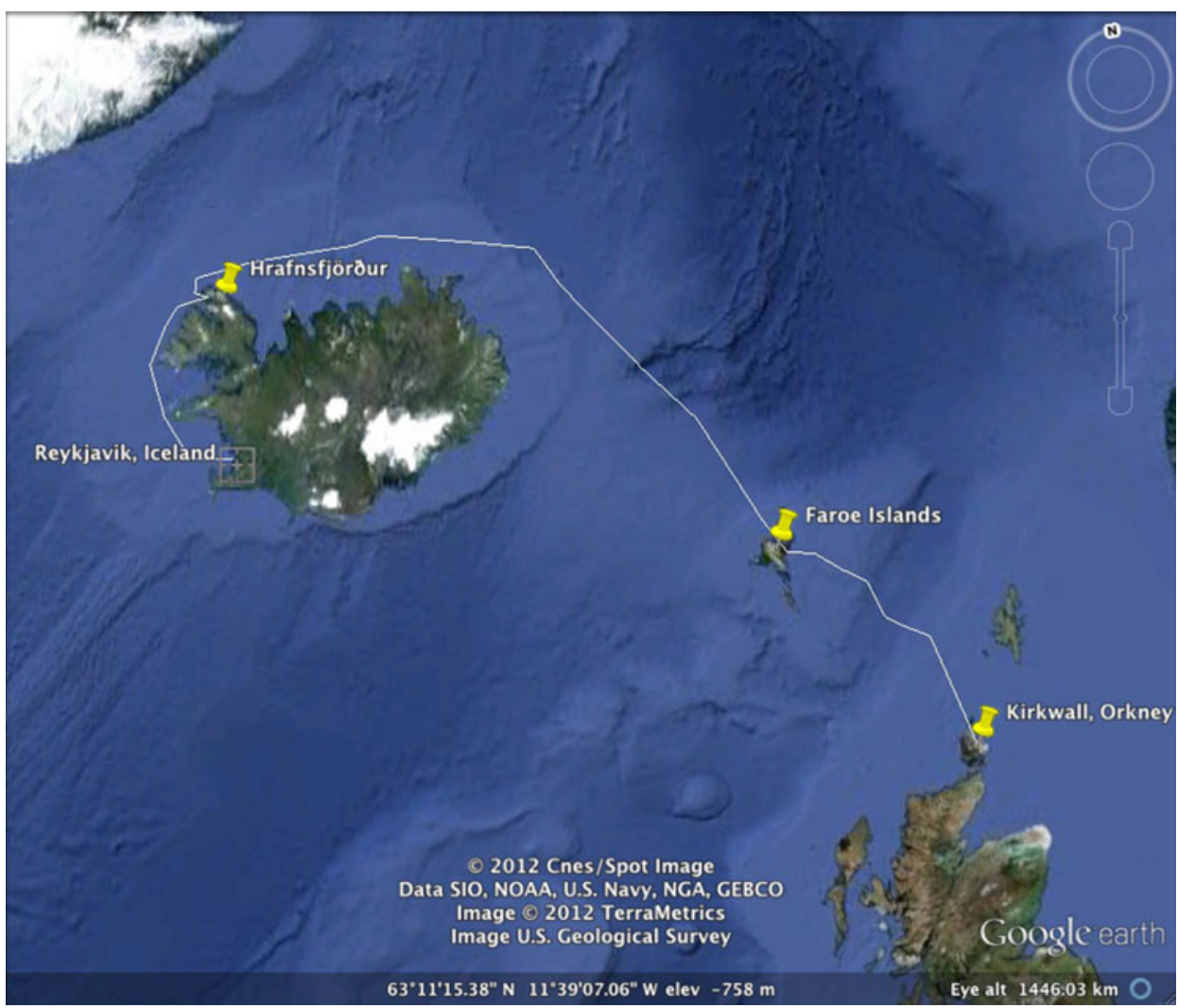

Figure 1. Route of Voyage (courtesy of Data SIO, NOAA, US Navy, NGA, GEBCO).

3. THE METHOD. Our navigation methods would be conventional as the aim of the voyage was to conduct observations safely and to be as certain as possible of our position at all times for reference purposes. For this reason a typical collection of instruments were available and used, including compasses, paper charts, electronic charts, Global Positioning System (GPS), Automatic Identification System (AIS) and radar.

I did not set out with a formal plan for collecting data as I knew it would not survive contact with the sea. The initial loose plan was as simple as keeping an hourly log and note any of the following observations, together with their exact positions:

- Bird numbers and species.

- Cetacean sightings.

- Other marine life.

- Flotsam.

- Seaweed.

- Anomalous clouds.

- Water behaviour and colour.

Fairly quickly a formal system did evolve, largely in response to the number of birds. It would be a full time business to note all birds sighted and it was a busy boat, so we settled on the following system. 
All extraordinary sightings of the items above would be noted, but a bird count would only be undertaken during a formal scan that occupied the final five minutes of each hour and then noted in that hour's log entry.

Part of the method was for us to use a common sense level of ornithological knowledge. We used Tony Soper's excellent book 'Wildlife of the North Atlantic' (Soper, 2008) to fill in any obvious gaps. But the aim was discover what it was possible for a navigator with average natural history knowledge levels to glean from their senses, not what a specialist could discern.

Inevitably on a short-handed small boat there were occasions when our workload precluded any formal count. There were also several instances when it was not possible due to fog.

For the purposes of this paper, 118 sightings were formally taken and the range was between $0 \cdot 3$ and $129 \cdot 4$ nautical miles $(\mathrm{nm})$ from land.

4. THE VOYAGE. The voyage from Kirkwall in the Orkney Islands, North into the Arctic Circle and then West and South down to Reykjavik is described here. Some context is given so that the reader can sample some of the experience of the voyage, not merely the observations.

During final preparations, I happened to notice a commercial vessel slipping her lines from the harbour wall at Kirkwall. My eye had been drawn to familiar shapes in a very unfamiliar place: there were cardinal mark buoys on the aft deck, one East mark and one South. Anyone conditioned to the familiar security of seeing these marks at sea cannot help but register some surprise on seeing them in such an unusual situation. I noted the name of this vessel: Pole Star (Figure 2). Seeing a vessel with such a name, and one that was venturing out to lay out navigation buoys, seemed a positive omen for a voyage in a much smaller boat that was itself shortly setting out to study natural navigation methods.

We slipped from Kirkwall at 1325 British Summer Time (BST) on the $19^{\text {th }}$ June 2012, under grey skies and occasional showers. The priority in the earliest part of the voyage was not noting observations of nature, but a safe exit of the Orkney archipelago. Previous experience in the Canary Islands had taught me that shorthanded departures from an island chain are times of intense concentration and high workload. My mind was focused on the lumps of rock that emerged, to varying degrees, from the water to the West of Shapinsay. One was of particular concern, the Skerry of Vasa. As we passed down the narrow channel to the East of it, we were rewarded for keeping a keen eye on this particular form with the sight of seals enjoying a rare afternoon sunbeam. My Mate and I conferred and concluded that the sight of seals basking on a rocky beach was a sure-fire indicator that land was not far away.

Pilot books, charts and local knowledge all concurred that my chosen exit route, the Westray Firth, was not a patch of water to be navigated lightly in the wrong conditions, namely a North Westerly gale. The chart was teeming with the squiggles of overfalls.

The value of these warnings became all too clear, even in light northerly winds, as the sea bumped and boiled and fair wrestled with the vessel. The art of tea-making in such conditions must be relearned at the start of each voyage.

As land slipped astern to the South, the sea state settled gradually from moderate to slight. A few hours later it was evening and bright still. The sky became filled with the 


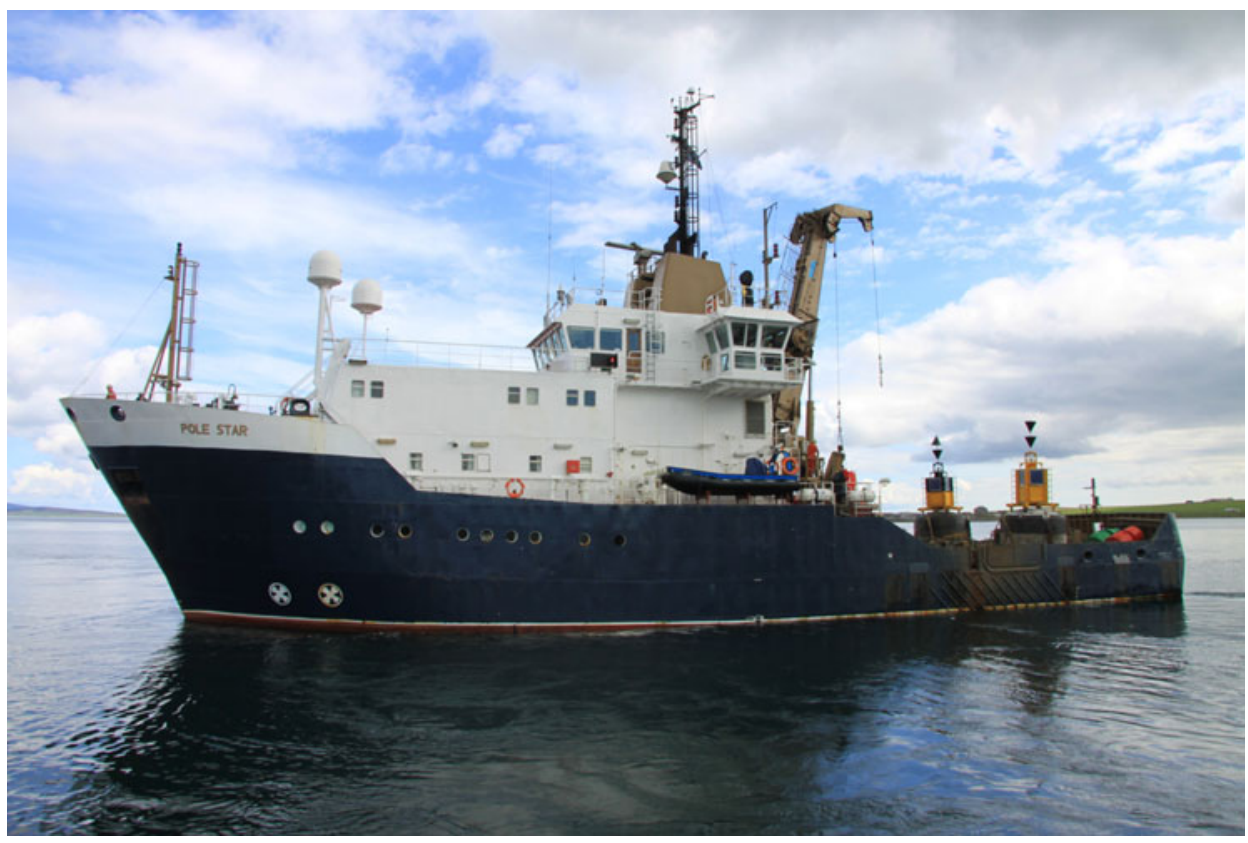

Figure 2. The Pole Star.

most extraordinary display of cirrus clouds. These were not merely mares' tails, but a sky full with tails and long lines of cirrus that stretched from overhead to the horizon and which resembled contrails in their straightness. Aside from the beauty they were not a welcome sight. I will not have been the first sailor to look at a blue sky scratched with cirrus and worried that a front was approaching. Knowledge that the forecast was good and that cirrus in isolation is not normally a cause for concern, if not followed by a progression of other clouds, such as cirrostratus and altostratus, allowed me to remain optimistic.

The first night at sea, if its feeble darkness could be called that, allowed the first and, it would transpire, only, view of the stars. The summer or navigator's triangle of Altair, Deneb and Vega were clear and the orange Arcturus shone brightly in the western sky. The Plough and Polaris were just visible, noticeably higher in the sky than I am accustomed to seeing them. Within an hour, at 0200 BST, light levels had risen enough to hide the stars. Not long before they disappeared, a flare from what I presumed to be the International Space Station lit the sky.

Early the following morning the wind died altogether and the sails came down. To conserve precious fuel I decided to prefer drifting to motoring at the start of the voyage.

The wind soon returned, this time from the South South East at about ten knots. The sails went back up; it was as good a way as we could think of to mark the summer solstice. The day passed without great event until a vessel we had been monitoring on our western horizon called us on channel 16. The survey vessel Ramform Viking was conducting seismic surveys and we needed to keep clear. Being told where to go by a 'Viking' seemed appropriate given the nature of our voyage. 
Several hours of course changes ensued, during which we honed our nature sighting techniques and finally settled on the final five minutes of the hour becoming the formal sighting time.

By this point it had already become clear that one of our dependable companions for the voyage would be the 'Northern Fulmar'. The Fulmar is a friendly bird, made less than beautiful by its nasal passages. But far more significant for our purposes than its appearance were the birds' habits and habitat. The Fulmar returns to land to breed, laying an egg in mid-May and incubating it for about 50 days. Outside of this period they are pelagic, spending very long periods, often several years, at sea. For navigation purposes this is valuable knowledge, as pelagic species are no guarantee of the proximity of land. Hence we found Fulmars at each stage of the journey, albeit in wildly varying numbers.

Wherever possible we identified the species of birds we saw, but where distance or other factors made an identification impossible, the key thing was for us to note whether the bird in question was a Fulmar or not.

So we settled into our hourly discipline of scanning all around the boat for 5 minutes at the end of each hour, counting and then noting the birds we saw during this period. We also noted any other nature observations of significance from the preceding 55 minutes, but bird sightings from this greater period were not included in the formal count.

A Fulmar sighting became a test as to whether either of us watch-keepers was actually alert or not and a failure to see any at all was a warning sign of drowsiness or carelessness - there was nearly always one or more to be found in close proximity to the yacht or somewhere in the distance. In 118 sightings there were only five occasions when a Fulmar failed to make an appearance. And there was not one single occasion when no birds could be seen, which I believe is significant for reasons I shall return to.

There are times when a skipper earns his keep and the decision of whether to proceed to route through the Faroe Islands became one of those moments. As we closed land we had a tidal gate we needed to make and we were running early. The tidal streams that run through the Faroe Islands have a reputation and they are not to be trifled with in a small yacht. My decision was to heave-to when we still had about $20 \mathrm{~nm}$ to run. I did not want us to be forced to claw our way from much closer if the decision was to leave the Islands to our West and go around. After heaving-to, the wind backed a little, becoming an easterly, and picked up to a Force 5. A Force 5 in sheltered waters is near-idyllic, but it felt much more like a Force 8 in this water and the sea state rose to 'moderate' very quickly. With a second reef in the mainsail and the boat pitching at each wave, the notorious tidal streams of the Faroes, that would welcome us if we proceeded, seemed foreboding.

However, the Faroes were part of the limited original plan, so I was hesitant to cancel them. Initially I felt there would be little choice, but it all boiled down to whether the weather change was the start of something more serious, or just a squall. It was the clearing sky that answered that and within four hours we were at the mouth of Kalsoyfjord and heading into one of the eeriest sailing channels I have had the pleasure of encountering.

For those planning this same route in a small boat, a word of warning may be warranted: no amount of cross-checking or cross-referencing our three sources of tidal flow information, before, during or after our passage, could make sense of the tidal streams we actually experienced. Despite timing our entrance to the exact minute we 


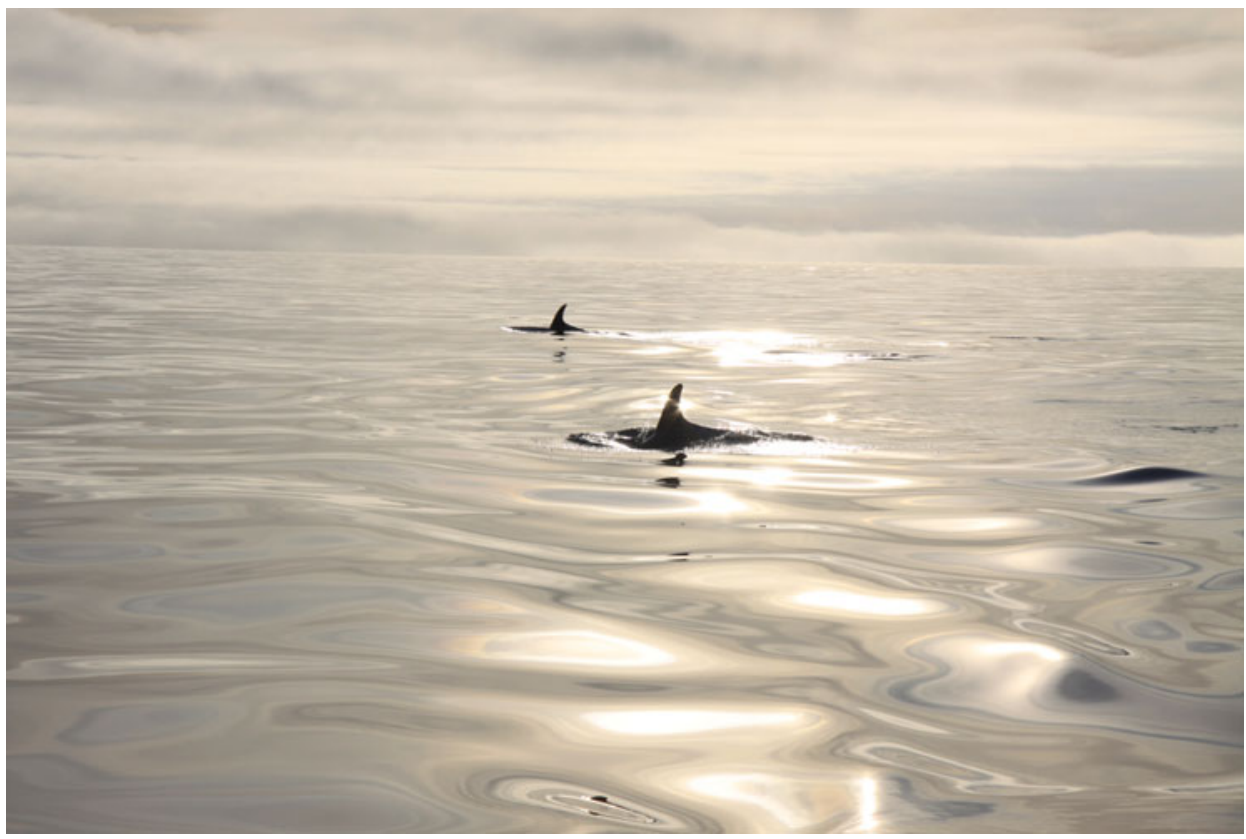

Figure 3. Long-Finned Pilot Whales sighted north of Iceland.

wanted and expecting at various stages to experience a following tidal stream of several knots, we did not experience one minute of tidal stream flowing with us, and plenty of strong flow against us. My suspicion is that this is one of those places where local knowledge is worth more than a dozen publications, as the truth gets lost somewhere between the two.

North of the Faroes we experienced another period of moderate seas and a few waves made their presence felt. One slightly roguish individual sent the boat a fair way over. The wind then died away and we were shrouded in a fog that plagued us for 24 hours. The fog did eventually lift and at 0400 on $25^{\text {th }}$ June 2012 we crossed the Arctic Circle about $65 \mathrm{~nm}$ East North East of Iceland. Shortly after entering the Arctic we saw our first cetacean, a Long-Finned Pilot Whale (Figure 3). The log soon began to reflect our latitude and one entry the following evening read, "Idyllic pottering in the night-time sun"; Figure 4 illustrates this.

At 0800 on $26^{\text {th }}$ June 2012 the mist lifted and we saw seaweed, rubbish and jellyfish in the water. One hour later a piece of driftwood was spotted and one hour after that the snow-covered mountains of Iceland became visible to the South. It was shortly after this that we reached our most northerly latitude, $67^{\circ} 01^{\prime}$ North.

The 2200 BST $\log$ entry on $26^{\text {th }}$ June 2012 contains the most mysterious episode in our voyage. During my formal 5 minute scan at the end of the hour, I noticed a vessel on the horizon. My only recollection of its shape was that it definitely had a vertical tower of some sort.

To conserve battery power, the chart-plotter, radar and AIS systems were kept off for most of the time and only switched on periodically, typically in poor visibility and once an hour for a safety and position check prior to each log entry. Switching on the systems, the vessel appeared very clearly on radar. It was closer than it had appeared, 


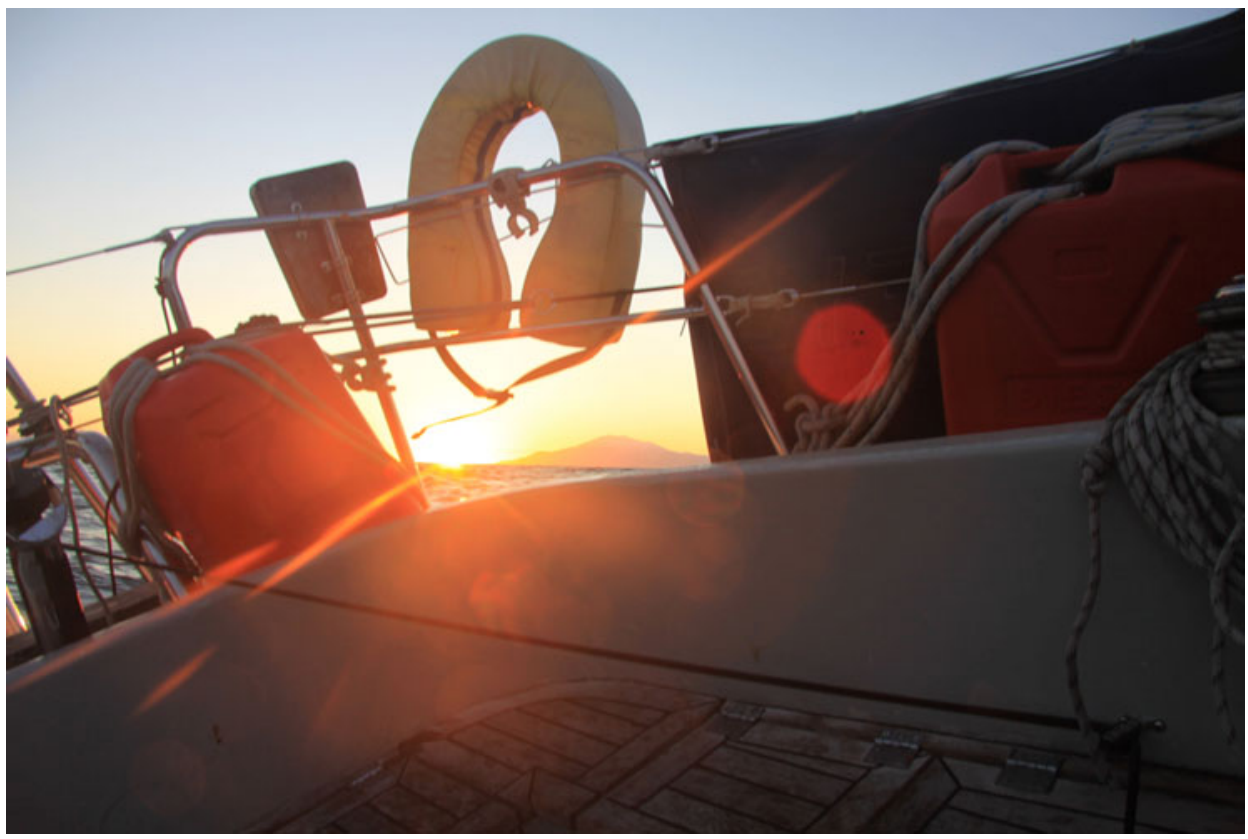

Figure 4. Heeled over in the middle of the night, looking North, off the West coast of Iceland.

only $2 \cdot 8 \mathrm{~nm}$ South West of our position, $66^{\circ} 51^{\prime}$ North $18^{\circ} 18^{\prime}$ West. It did not register on our basic AIS system, but that was not unusual, as many vessels failed to register or registered sporadically for unknown reasons.

One thing was unusual, however, my boat is fitted with an active radar reflection system, made by SeaMe. The power panel for this includes a red LED light which activates whenever the system detects another vessel's radar. This was as dependable as any electronic system we had on the boat for alerting us to the presence of other vessels in our vicinity, and yet on this occasion it did not show us being 'swept' by radar. Approximately five minutes after sighting this vessel it disappeared completely, off radar and out of sight, and did not return. We had VHF Channel 16 selected and I raised the volume on this and upped my vigilance levels for any other clues to distress, but there were none.

Exactly the same thing happened 13 hours later. More experienced sailors than I may be able to explain this, our only guess was that it may have been a submarine.

Between these two 'sightings' something less mysterious and more magisterial took place during the early hours of the $27^{\text {th }}$ June. Dolphins came to play off the bow wave. This was especially generous of them as a Contessa 32 does not cut much of a bow wave at any time and certainly not under sail in a Force 3.

Our course took us to the North West tip of Iceland, a stark, beautiful and largely uninhabited region. We cut inside an area of overfalls, made our way around the headland and then prepared ourselves for a small adventure. We headed East up a long fjord, towards a glacier, and then continued further into one of the fjords extremities. Here the charts, both paper and electronic, turned white as we were now in uncharted waters with no soundings shown. Not for long, barely an hour, but anyone with a passion for navigation will understand the strange thrill that comes from sailing in water that is blank on the chart. 


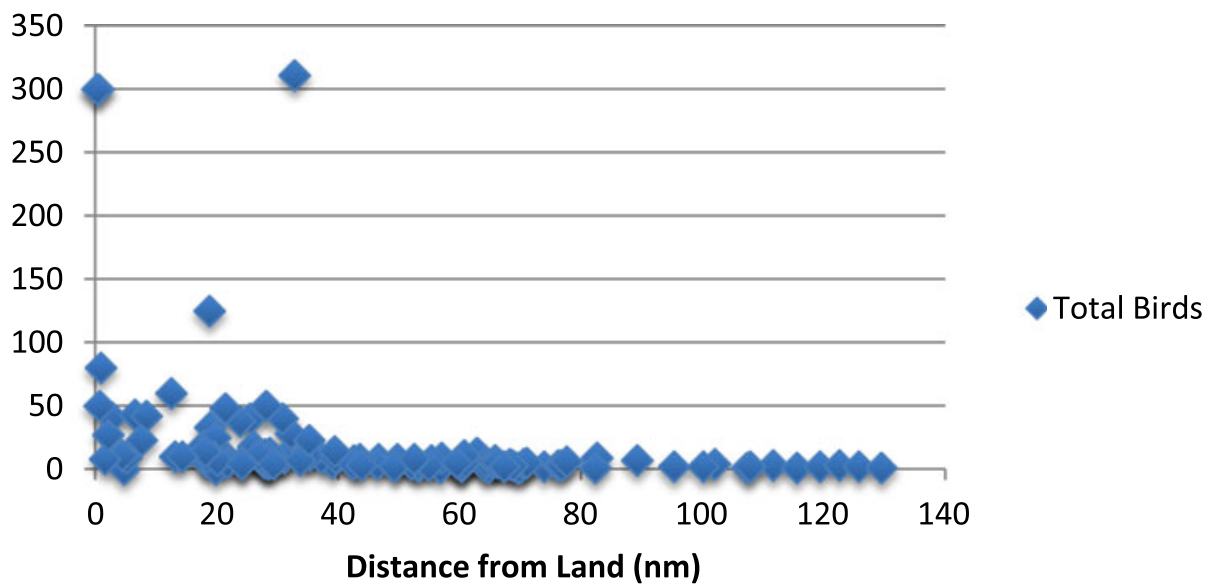

Figure 5. The total number of birds counted in 5 minute scan plotted against distance from land.

I took the tiller and John stood at the bow ready to report any rocks in the clear water of Hrafnsfjörður. Our depth dropped to just under 5 metres at times, but the fjord released us unscathed. As one pilot book has already noted (Ker, 2004) and we can confirm, safe passage was possible by following a line just South of the centre line.

From there we made our way down the West coast of Iceland. At times we contended with tidal rips that threw the boat around and fierce katabatic winds that turned light winds into a Force 7. But it was all enjoyable.

At midday on $30^{\text {th }}$ June 2012 we moored in Reykjavik. There were a collection of other yachts moored in the yacht club marina. It was the first time we had seen a sailing vessel of any description since leaving Kirkwall.

5. THE BIRDS. It was clear very early on in the voyage that the number of birds we counted bore some relationship to our proximity to land. Occasional sightings were anomalous, but a trend was discernible at sea, even before looking at the detailed data shown in Figure 5. After analysing all the observation data, the relationship became clearer still. On 39 occasions our total bird count, Fulmars and others, reached double figures. On only 2 of these 39 occasions were we more than $40 \mathrm{~nm}$ from land $(62 \cdot 8 \mathrm{~nm}$ and $60.7 \mathrm{~nm}$ ). Based on these figures, a skipper in these waters at this time of year, denied all instruments, could hazard a guess, as demonstrated by Figure 6, that if they counted 10 or more birds in a random 5 minute period there is a near $95 \%$ probability of land within $40 \mathrm{~nm}$.

Conversely there were 27 occasions when we counted an 'all species' total, of three or fewer birds. On only two of these 27 occasions were we less than $50 \mathrm{~nm}$ from land $(49 \cdot 2 \mathrm{~nm}$ and $43 \cdot 8 \mathrm{~nm})$. These figures would suggest that a count of three or fewer birds in a random five minute period would allow a guess that there is a greater than $90 \%$ likelihood that land is more than $50 \mathrm{~nm}$ away.

The beauty of grouping the birds together, pelagic and non-pelagic, is that the skill, knowledge and time necessary to do the exercise is greatly reduced, making it of interest and value to a greater number hopefully. 


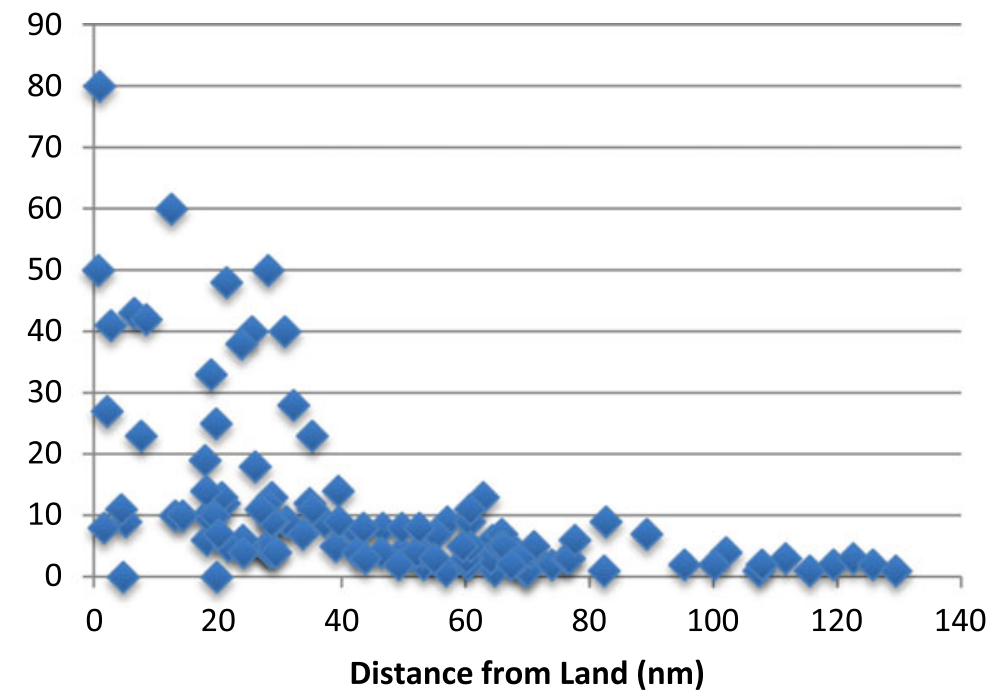

Total Birds

Figure 6. The number of birds counted in 5 minute scan plotted against distance from land. Bird counts of more than 100 excluded.

However, the Pacific Island navigators certainly and doubtless the Vikings too, became adept at the lessons each species were offering. Since all non-pelagic birds have their own comfortable range from land, the Pacific navigators were able to use this knowledge to their advantage. Frigate birds range further than boobies, which will typically venture further from land than terns. This method can be used as a means of target-enlargement by any navigator with the local knowledge. We were not sailing the same waters for long enough to build substantial insight into this particular method, with two exceptions, the puffin and the Guillemot.

The Atlantic Puffin is pelagic, like the Fulmar, and only comes ashore to breed in April. However, it thrives in Icelandic waters and sure enough the numbers of puffins we saw when were we were within $40 \mathrm{~nm}$ of Iceland was remarkable.

The Guillemot is non-pelagic and so unsurprisingly, the seven recorded sightings we made were all within $40 \mathrm{~nm}$ of land. We were not able to verify a rather wonderful natural navigation clue that we read in Soper (2008). Guillemots are brown in colour at the southern end of their range, but grow darker as you head North.

The other species of bird that we saw during the voyage included various gulls, including the Black Backed and Kittiwake, Arctic Skuas, Arctic Terns, Young Gannets and Northern Gannets. None of these led us to any individual conclusions, although they all played their part admirably as constituents of the aggregated counts.

If we exclude the three occasions when more than 100 birds were sighted, not because they fail to fit the trend (they clearly do), but solely because it makes a visual presentation of the data slightly easier to interpret, the importance of the $40 \mathrm{~nm}$ range from land becomes clearer (Figure 6).

6. THE CLOUDS. At 1800 BST on $21^{\text {st }}$ June 2012 we saw unusual cloud formations to the West and North West. While clouds in all other directions were of 
the stratified variety, in the distance to our North West and West we could see cumulus that was bubbling up substantially. The clouds were too large to be of the fair weather variety of cumulus, and not vertical enough to be categorized as towering cumulus. At this stage we were at $61^{\circ} 52^{\prime}$ North $5^{\circ} 33^{\prime}$ West, and land was not visible. According to the chart, we knew it to be $31 \mathrm{~nm}$ in the direction of these clouds. Two hours later and 12 miles closer to the Faroe Islands, we sighted their dark cliffs; these anomalous clouds were indeed found to be amassed only over the land.

By contrast, I should point out that at 1300 BST on $24^{\text {th }}$ June 2012 I noticed another bank of similar anomalous clouds to the North West. We were at $65^{\circ} 49^{\prime}$ North $11^{\circ} 8^{\prime}$ West, which is $64 \mathrm{~nm}$ East of Iceland. These clouds proved to have no obvious relationship to the land to the West of us.

The only other clouds of navigational interest were the low ones in the form of fog, which we encountered regularly and which made both safe navigation and observations much more challenging.

Finally, there were man-made clouds in the form of contrails. The few contrails we observed (only two during the formal sighting period) generally conformed to the trend for that part of the Atlantic, that is that they traced a line approximately North West/South East in the sky.

7. THE WATER. The natural navigators of the Pacific relied heavily on an understanding of swell patterns, especially when there was cloud cover. There were occasions on our voyage when the swell patterns were very easy to read and many more when it was challenging to confusing. In the middle of the day on $21^{\text {st }}$ June 2012 there were two distinct swells that were very easy to read, one coming from the South and one from the South East. It would have been easy to set a course by these, such was the ease of reading them. At most other times it may have been possible, but I would not have wanted to rely on the swell for direction for long periods, without a lot more practice.

An interesting clue to our location came in the abrupt and dramatic change in water colour that we could not help but notice off the North coast of Iceland. At 1500 on $27^{\text {th }}$ June 2012 at $66^{\circ} 52^{\prime}$ North $20^{\circ} 54^{\prime}$ West, some $44 \mathrm{~nm}$ off the North West coast of Iceland, the colour of the water changed completely from a typical dull and dark grey/ blue to a much lighter greener colour that approached turquoise. Five hours and $29 \mathrm{~nm}$ West South West of that position, the colour reverted back to the duller, darker grey/blue. Not being very familiar with the exact current patterns in that part of the world, we could not make any firm conclusions about our location from those observations, but we did think that regular sailors of those waters probably could have done.

The pilot book (Ker, 2004) revealed that we were probably temporarily leaving the Irminger current and cutting across a section of the East Greenland Current. One possibility, which I cannot confirm, is that since this current has a lot of melted ice water in it, and consequently lower salinity, microorganisms can flourish and add a greener colour. The logbook also reveals that we felt a serious chill at this time too and we noted "This $N$ wind has a bite to it".

Perhaps the strongest clues to location, with reference to the proximity of land at least, came not in the water itself, but in the things we found in the water. 


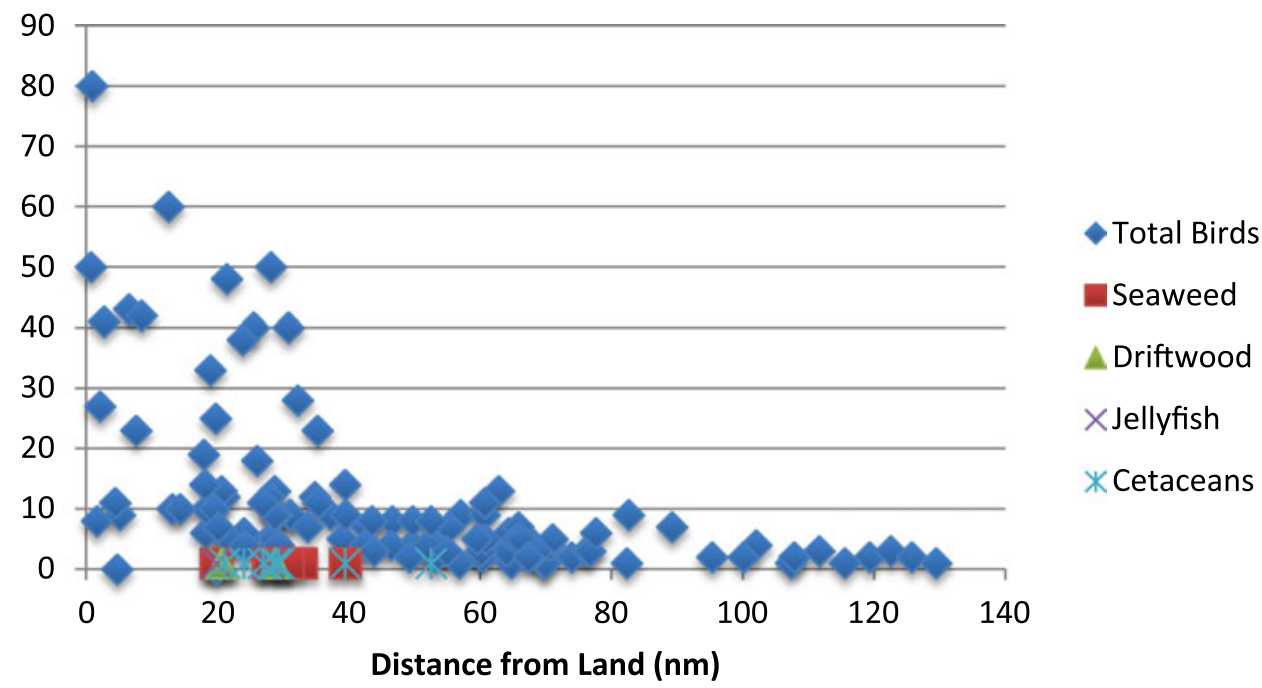

Figure 7. Total birds (excluding sightings of more than 100), cetaceans, driftwood, jellyfish and seaweed sightings plotted against distance from land.

8. FLOTSAM, SEAWEED AND JELLYFISH. We noted four instances of man-made rubbish in the water, the greatest distance from land was $42.4 \mathrm{~nm}$. We saw driftwood in the water on two occasions, at distances from land of $28.7 \mathrm{~nm}$ and $20.6 \mathrm{~nm}$. Seaweed and jellyfish sightings followed a comparable pattern to flotsam. We counted six instances of seeing seaweed in the water, the greatest distance from land was $39 \cdot 5 \mathrm{~nm}$. Jellyfish were sighted on four occasions, all between $19 \mathrm{~nm}$ and $30 \mathrm{~nm}$ from land.

Individually not much weight can be attached to any one of these sightings, but as a group pattern it is interesting. $40 \%$ (i.e., 47) of all our formal recorded observations were more than $45 \mathrm{~nm}$ from land and yet none of our sightings of rubbish, driftwood, seaweed or jellyfish were found in that group (see Figure 7).

9. CETACEANS. We saw four instances of Long-Finned Pilot Whales, a school of dolphins and an individual Humpback whale. All these sightings took place in the range of $21.0 \mathrm{~nm}$ to $52.5 \mathrm{~nm}$ from land (see Figure 7).

10. THE SURPRISE. The simple aims of this expedition were fairly clear: to observe and note nature's clues to location, with emphasis on distance from land. However, there was one result which came as a pleasant surprise. It transpired that the act of scanning for natural clues, and birds in particular, led to substantially better watch-keeping in general.

I believe that the Fulmar played an important role in this, since we were almost guaranteed to be able to find something to note, even if on occasion this required patience and concentration during a 5 minute period. This meant that we started to notice things that would otherwise have gone unspotted. It was uncanny the number of times that we spotted a vessel on the horizon during the last 5 minutes of each 
watch. Since the probability of vessels appearing on the horizon can be assumed to be as likely at any point during the first 55 minutes of the hour as the final 5 , the only logical conclusion is that this act of searching for birds allowed us to spot many more vessels. There was a distinct improvement in safety that resulted from looking for birds.

This may offer food for thought for skippers on vessels of all sizes who want their crew to be at their most alert. A bland instruction to 'keep a good lookout' may or may not lead to the desired result. An instruction to note the numbers and species of birds before each log entry, may possibly do more to achieve this aim.

11. CAVEAT. It is necessary for me to underline that $\mathrm{I}$ am not in any way advocating any of these methods for primary navigation. I am merely presenting this limited data and the message within it: patterns in nature are not random and the distance from land is one factor that influences what we see.

12. CONCLUSIONS. The voyage was challenging to plan and execute, but achieved its main aim and also led to one unexpected result that may be of value in a much broader context.

The observations and data collected during this passage reinforce our understanding of what is possible without the aid of electronic navigation. The author is certain that an awareness of the proximity of land can be aided by an interest in natural navigation clues and $40 \mathrm{~nm}$ from land proved to be a critical range in these waters. This awareness can serve as a 'gross error check' on primary systems, including satellite navigation. On the occasions when such clues do not prove of practical value, an interest in natural navigation will still lead to a more interesting voyage for the navigator. It certainly leads to a richer logbook.

The author is more convinced than ever (Gooley, 2010) that the navigator who makes little effort to notice the clues that nature offers will experience a very pallid journey compared to the one that invests this time and effort. As technological innovation progresses apace and the proportion of those at sea with experience of using these methods in any way diminishes, there is a danger that our whole understanding of what it means to be at sea is steadily metamorphosing into something less desirable: a pale imitation of what it once was. This is a view that is likely to be shared by those who believe that navigation can be much more than a purely pragmatic art. Navigation can be one of the keys to unlocking the richness that lies between our points of departure and arrival and this paper supports this broader philosophy.

Navigation can take on a fresh and fascinating life when it is not constrained by considerations solely of necessity and safety. However, it need not be a choice between safety and richness of experience. Natural navigation methods can offer both a more interesting experience for the navigator and improved safety.

There are sometimes unforeseen benefits to a raised level of awareness at sea. The act of looking for these natural navigation clues in a formal way (during the last five minutes of each hour) led to improved discovery of other vessels. There were a disproportionate number of first sightings of vessels during this period. There are some safety implications and potential benefits of this 'accidental improved watch-keeping'. 
The sly skipper who wishes to raise the standard of watch-keeping on a vessel could do worse than implement a similar simple system of counting and noting birds in the log.

\section{REFERENCES}

Cunliffe, B. (2002). The Extraordinary Voyage of Pytheas the Greek. Walker Publishing Company, Inc.

Encyclopædia Britannica (2012a). Guglielmo Marconi. Encyclopædia Britannica Online. Accessed $2^{\text {nd }}$ August 2012, http://www.britannica.com/EBchecked/topic/364287/Guglielmo-Marconi.

Encyclopædia Britannica (2012b). Erik the Red. Encyclopædia Britannica Online. Accessed $3^{\text {rd }}$ August 2012, http://www.britannica.com/EBchecked/topic/191529/Erik-the-Red.

George, M. (2012). Polynesian Navigation and Te Lapa-The Flashing. Time and Mind: The Journal of Archaeology, Consciousness and Culture, 5(2), 135-174.

Gooley, T. (2010). The Natural Navigator. Virgin Books.

Ker, W. (2004). Faroe, Iceland and Greenland. Imray, Laurie, Norie \& Wilson Ltd.

Lewis, D. (1972). We, the Navigators. University of Hawaii Press.

Lewis, D. and George, M. (1991). Hunters and Herders: Chukchi and Siberian Eskimo Navigation Across Snow and Frozen Sea. The Journal of Navigation, 44, 1-10.

Soper, T. (2008). Wildlife of the North Atlantic. Bradt Travel Guides Ltd.

Thirslund, S. (1997) Sailing Directions of the North Atlantic Viking Age (from about the year 860 to 1400). The Journal of Navigation. 50, 55-64. 
APPENDIX A

OBSERVATIONAL DATA: GOLDENEYE KIRKWALL TO REYKJAVIK $20^{\text {th }}$ to $28^{\text {th }}$ JUNE 2012

Table A1. Observational Data: Goldeneye Kirkwall to Reykjavik.

\begin{tabular}{|c|c|c|c|c|c|c|c|}
\hline $\begin{array}{l}\text { June } 2012 \\
\text { Date/Time } \\
\text { (BST) }\end{array}$ & Latitude & Longitude & $\begin{array}{l}\text { Distance from } \\
\text { Nearest Land } \\
(\mathrm{nm}) / \text { Identity }\end{array}$ & Fulmars & $\begin{array}{l}\text { Other } \\
\text { Birds }\end{array}$ & $\begin{array}{l}\text { Total } \\
\text { Birds }\end{array}$ & $\begin{array}{c}\text { Relevant } \\
\text { Observations }\end{array}$ \\
\hline $20 / 1700$ & $60^{\circ} 25 \cdot 6^{\prime} \mathrm{N}$ & $03^{\circ} 33 \cdot 7^{\prime} \mathrm{W}$ & $46 \cdot 6^{\prime} /$ Foula & 8 & 0 & 8 & \\
\hline $20 / 1800$ & $60^{\circ} 28 \cdot 3^{\prime} \mathrm{N}$ & $03^{\circ} 38 \cdot 0^{\prime} \mathrm{W}$ & $49 \cdot 6^{\prime} /$ Foula & 3 & 1 & 4 & Northern Gannet. \\
\hline $20 / 1900$ & $60^{\circ} 31 \cdot 3^{\prime} \mathrm{N}$ & $03^{\circ} 42 \cdot 9^{\prime} \mathrm{W}$ & $53 \cdot 2^{\prime} /$ Foula & 2 & 0 & 2 & \\
\hline $20 / 2000$ & $60^{\circ} 34 \cdot 8^{\prime} \mathrm{N}$ & $03^{\circ} 47 \cdot 7^{\prime} \mathrm{W}$ & $56 \cdot 8^{\prime} /$ Foula & 1 & 0 & 1 & \\
\hline $20 / 2100$ & $60^{\circ} 37 \cdot 6^{\prime} \mathrm{N}$ & $03^{\circ} 52 \cdot 7^{\prime} \mathrm{W}$ & $60 \cdot 3^{\prime} /$ Foula & 1 & 1 & 2 & Unidentified non-Fulmar. \\
\hline $20 / 2200$ & $60^{\circ} 40 \cdot 2^{\prime} \mathrm{N}$ & $03^{\circ} 59 \cdot 8^{\prime} \mathrm{W}$ & $64 \cdot 7^{\prime} /$ Foula & 1 & 0 & 1 & \\
\hline $21 / 0000$ & $60^{\circ} 46 \cdot 6^{\prime} \mathrm{N}$ & $04^{\circ} 03 \cdot 3^{\prime} \mathrm{W}$ & $69 \cdot 5^{\prime} /$ Foula & 1 & 0 & 1 & \\
\hline $21 / 0100$ & $60^{\circ} 48 \cdot 1^{\prime} \mathrm{N}$ & $04^{\circ} 02 \cdot 8^{\prime} \mathrm{W}$ & $69 \cdot 9^{\prime} /$ Foula & 1 & 0 & 1 & \\
\hline $21 / 0200$ & $60^{\circ} 48 \cdot 2^{\prime} \mathrm{N}$ & $04^{\circ} 04 \cdot 2^{\prime} \mathrm{W}$ & $70 \cdot 5^{\prime} /$ Foula & 2 & 2 & 4 & Unidentified. \\
\hline $21 / 0300$ & $60^{\circ} 48 \cdot 2^{\prime} \mathrm{N}$ & $04^{\circ} 12 \cdot 0^{\prime} \mathrm{W}$ & $73 \cdot 9^{\prime} /$ Foula & 2 & 0 & 2 & \\
\hline $21 / 0400$ & $60^{\circ} 51 \cdot 2^{\prime} \mathrm{N}$ & $04^{\circ} 18 \cdot 6^{\prime} \mathrm{W}$ & $76 \cdot 2^{\prime}$ Suduroyarfjordur & 1 & 2 & 3 & Probably Puffin, plus Young Gannet. \\
\hline $21 / 0500$ & $60^{\circ} 54 \cdot 7^{\prime} \mathrm{N}$ & $04^{\circ} 24 \cdot 3^{\prime} \mathrm{W}$ & $76 \cdot 7^{\prime}$ Suduroyarfjordur & 1 & 2 & 3 & 2 distant unidentified non-Fulmars. \\
\hline $21 / 0600$ & $60^{\circ} 59 \cdot 1^{\prime} \mathrm{N}$ & $04^{\circ} 29 \cdot 7^{\prime} \mathrm{W}$ & $68 \cdot 2^{\prime}$ Suduroyarfjordur & 3 & 1 & 4 & One distant, unidentified. \\
\hline $21 / 0700$ & $61^{\circ} 05 \cdot 2^{\prime} \mathrm{N}$ & $04^{\circ} 34 \cdot 4^{\prime} \mathrm{W}$ & $64 \cdot 0^{\prime}$ Suduroyarfjordur & 3 & 0 & 3 & \\
\hline $21 / 0800$ & $61^{\circ} 10 \cdot 8^{\prime} \mathrm{N}$ & $04^{\circ} 38 \cdot 5^{\prime} \mathrm{W}$ & $60 \cdot 2^{\prime}$ Suduroyarfjordur & 3 & 0 & 3 & \\
\hline $21 / 0900$ & $61^{\circ} 16 \cdot 3^{\prime} \mathrm{N}$ & $04^{\circ} 42 \cdot 9^{\prime} \mathrm{W}$ & $57 \cdot 0^{\prime}$ Suduroyarfjordur & 9 & 0 & 9 & Fulmars in a clump. \\
\hline $21 / 1000$ & $61^{\circ} 21 \cdot 5^{\prime} \mathrm{N}$ & $04^{\circ} 46 \cdot 5^{\prime} \mathrm{W}$ & $55 \cdot 3^{\prime}$ Suduroyarfjordur & 3 & 4 & 7 & Small, distant, fast, low, possibly puffins. \\
\hline $21 / 1100$ & $61^{\circ} 26 \cdot 4^{\prime} \mathrm{N}$ & $04^{\circ} 50 \cdot 0^{\prime} \mathrm{W}$ & $53 \cdot 0^{\prime}$ Suduroyarfjordur & 4 & 0 & 4 & Distinct swells from $\mathrm{S}$ and SE. \\
\hline $21 / 1200$ & $61^{\circ} 30 \cdot 5^{\prime} \mathrm{N}$ & $04^{\circ} 53 \cdot 6^{\prime} \mathrm{W}$ & $52 \cdot 0^{\prime}$ Suduroyarfjordur & 4 & 0 & 4 & Distinct swells from $\mathrm{S}$ and $\mathrm{SE}$. \\
\hline $21 / 1300$ & $61^{\circ} 33 \cdot 9^{\prime} \mathrm{N}$ & $04^{\circ} 58 \cdot 2^{\prime} \mathrm{W}$ & $49 \cdot 7^{\prime} /$ Sandoy & 8 & 0 & 8 & Distinct swells from $\mathrm{S}$ and $\mathrm{SE}$. \\
\hline $21 / 1400$ & $61^{\circ} 37 \cdot 6^{\prime} \mathrm{N}$ & $05^{\circ} 03 \cdot 8^{\prime} \mathrm{W}$ & $46 \cdot 4^{\prime} /$ Sandoy & 4 & 0 & 4 & \\
\hline $21 / 1500$ & $61^{\circ} 41 \cdot 2^{\prime} \mathrm{N}$ & $05^{\circ} 10 \cdot 5^{\prime} \mathrm{W}$ & $42 \cdot 6^{\prime} /$ Sandoy & 7 & 0 & 7 & \\
\hline $21 / 1600$ & $61^{\circ} 44 \cdot 4^{\prime} \mathrm{N}$ & $05^{\circ} 17 \cdot 6^{\prime} \mathrm{W}$ & $39 \cdot 0^{\prime} /$ Sandoy & 5 & 0 & 5 & \\
\hline $21 / 1700$ & $61^{\circ} 47 \cdot 9^{\prime} \mathrm{N}$ & $05^{\circ} 25 \cdot 1^{\prime} \mathrm{W}$ & $34 \cdot 8^{\prime} /$ Sandoy & 12 & 0 & 12 & 2 parallel contrails, $\mathrm{NW}$ to $\mathrm{SE}$. \\
\hline $21 / 1800$ & $61^{\circ} 51 \cdot 5^{\prime} \mathrm{N}$ & $05^{\circ} 32 \cdot 6^{\prime} \mathrm{W}$ & $31 \cdot 0^{\prime} /$ Nolsoy & 9 & 0 & 9 & Bubbling cumulus only to $\mathrm{W}$ and NW. \\
\hline $21 / 1900$ & $61^{\circ} 56 \cdot 2^{\prime} \mathrm{N}$ & $05^{\circ} 41 \cdot 6^{\prime} \mathrm{W}$ & $26 \cdot 0^{\prime} /$ Bordoy & 18 & 0 & 18 & Banks of cumulus to $\mathrm{W}$ and $\mathrm{NW}$ only. \\
\hline
\end{tabular}


Table A1 (Cont.)

\begin{tabular}{|c|c|c|c|c|c|c|c|}
\hline $\begin{array}{l}\text { June } 2012 \\
\text { Date/Time } \\
\text { (BST) }\end{array}$ & Latitude & Longitude & $\begin{array}{l}\text { Distance from } \\
\text { Nearest Land } \\
(\mathrm{nm}) / \text { Identity }\end{array}$ & Fulmars & $\begin{array}{l}\text { Other } \\
\text { Birds }\end{array}$ & $\begin{array}{l}\text { Total } \\
\text { Birds }\end{array}$ & $\begin{array}{c}\text { Relevant } \\
\text { Observations }\end{array}$ \\
\hline $21 / 2000$ & $62^{\circ} 01 \cdot 6^{\prime} \mathrm{N}$ & $05^{\circ} 50 \cdot 7^{\prime} \mathrm{W}$ & $18 \cdot 9^{\prime} /$ Bordoy & 32 & 1 & 33 & Land sighted under cumulus banks. Bird unidentified. \\
\hline $21 / 2100$ & $62^{\circ} 01 \cdot 9^{\prime} \mathrm{N}$ & $05^{\circ} 52 \cdot 8^{\prime} \mathrm{W}$ & $17 \cdot 9^{\prime} /$ Svinoy & 15 & 4 & 19 & Mostly Fulmars, too busy to identify. \\
\hline $21 / 2200$ & $62^{\circ} 01 \cdot 0^{\prime} \mathrm{N}$ & $05^{\circ} 54 \cdot 4^{\prime} \mathrm{W}$ & $18 \cdot 2^{\prime} /$ Bordoy & 3 & 3 & 6 & Mixed. Too busy to identify. \\
\hline $22 / 0000$ & $62^{\circ} 04 \cdot 8^{\prime} \mathrm{N}$ & $06^{\circ} 02 \cdot 0^{\prime} \mathrm{W}$ & $13 \cdot 1^{\prime} /$ Bordoy & 10 & 0 & 10 & Two radar contacts. \\
\hline $22 / 0200$ & $62^{\circ} 06 \cdot 9^{\prime} \mathrm{N}$ & $06^{\circ} 11 \cdot 0^{\prime} \mathrm{W}$ & $4 \cdot 7^{\prime} /$ Bordoy & & & & Fishing boat visible. \\
\hline $22 / 0350$ & $62^{\circ} 15 \cdot 4^{\prime} \mathrm{N}$ & $06^{\circ} 39 \cdot 9^{\prime} \mathrm{W}$ & $0 \cdot 5^{\prime} /$ Kunoy & 200 & 100 & 300 & Fulmars and puffins mainly. Numbers estimated. \\
\hline $22 / 0600$ & $62^{\circ} 20 \cdot 3^{\prime} \mathrm{N}$ & $06^{\circ} 43 \cdot 3^{\prime} \mathrm{W}$ & $0 \cdot 3^{\prime} /$ Kunoy & 200 & 100 & 300 & Fulmars and puffins mainly. Numbers estimated. \\
\hline $22 / 0700$ & $62^{\circ} 24 \cdot 3^{\prime} \mathrm{N}$ & $06^{\circ} 47 \cdot 8^{\prime} \mathrm{W}$ & $2 \cdot 7^{\prime} /$ Kalsoy & 15 & 26 & 41 & Puffins, Fulmars and Gulls. Ratio estimated. \\
\hline $22 / 0800$ & $62^{\circ} 28 \cdot 1^{\prime} \mathrm{N}$ & $06^{\circ} 54 \cdot 9^{\prime} \mathrm{W}$ & $6 \cdot 5^{\prime} /$ Kalsoy & 23 & 20 & 43 & Fulmars and Gulls. Ratio estimated. \\
\hline $22 / 0900$ & $62^{\circ} 33 \cdot 2^{\prime} \mathrm{N}$ & $07^{\circ} 01 \cdot 6^{\prime} \mathrm{W}$ & $12 \cdot 5^{\prime} / \mathrm{Kalsoy}$ & 35 & 25 & 60 & Fulmars and Black Backed Gulls. Ratio estimated. \\
\hline $22 / 1000$ & $62^{\circ} 39 \cdot 0^{\prime} \mathrm{N}$ & $07^{\circ} 07 \cdot 2^{\prime} \mathrm{W}$ & $18 \cdot 8^{\prime} /$ Kalsoy & 24 & 101 & 125 & Black Backed Gulls plus 1 unidentified. \\
\hline $22 / 1100$ & $62^{\circ} 45 \cdot 2^{\prime} \mathrm{N}$ & $07^{\circ} 11 \cdot 7^{\prime} \mathrm{W}$ & $25 \cdot 5^{\prime} /$ Kalsoy & 0 & 40 & 40 & Kittiwakes. \\
\hline $22 / 1200$ & $62^{\circ} 50 \cdot 3^{\prime} \mathrm{N}$ & $07^{\circ} 16 \cdot 1^{\prime} \mathrm{W}$ & $31 \cdot 1^{\prime} /$ Kalsoy & 5 & 4 & 9 & Ratio estimated as distant. \\
\hline $22 / 1300$ & $62^{\circ} 56 \cdot 1^{\prime} \mathrm{N}$ & $07^{\circ} 21 \cdot 3^{\prime} \mathrm{W}$ & $37 \cdot 2^{\prime} /$ Kalsoy & 0 & 9 & 9 & Gulls. \\
\hline $22 / 1400$ & $63^{\circ} 01 \cdot 6^{\prime} \mathrm{N}$ & $07^{\circ} 27 \cdot 5^{\prime} \mathrm{W}$ & $43 \cdot 5^{\prime} /$ Kalsoy & 3 & 5 & 8 & \\
\hline $22 / 1500$ & $63^{\circ} 06 \cdot 7^{\prime} \mathrm{N}$ & $07^{\circ} 33 \cdot 8^{\prime} \mathrm{W}$ & $49 \cdot 2^{\prime} /$ Kalsoy & 2 & 0 & 2 & \\
\hline $22 / 1600$ & $63^{\circ} 11 \cdot 9^{\prime} \mathrm{N}$ & $07^{\circ} 38 \cdot 8^{\prime} \mathrm{W}$ & $54 \cdot 9^{\prime} /$ Kalsoy & 3 & 0 & 3 & \\
\hline $22 / 1700$ & $63^{\circ} 16 \cdot 8^{\prime} \mathrm{N}$ & $07^{\circ} 42 \cdot 8^{\prime} \mathrm{W}$ & $60 \cdot 1^{\prime} /$ Kalsoy & 3 & 0 & 3 & \\
\hline $22 / 1800$ & $63^{\circ} 21 \cdot 7^{\prime} \mathrm{N}$ & $07^{\circ} 49 \cdot 6^{\prime} \mathrm{W}$ & $66 \cdot 0^{\prime} /$ Kalsoy & 6 & 0 & 6 & Distant. \\
\hline $22 / 1900$ & $63^{\circ} 26 \cdot 0^{\prime} \mathrm{N}$ & $07^{\circ} 55 \cdot 8^{\prime} \mathrm{W}$ & $71 \cdot 0^{\prime} /$ Eysturoy & 5 & 0 & 5 & \\
\hline $22 / 2000$ & $63^{\circ} 31 \cdot 9^{\prime} \mathrm{N}$ & $08^{\circ} 02 \cdot 0^{\prime} \mathrm{W}$ & $77 \cdot 6^{\prime} /$ Eysturoy & 6 & 0 & 6 & Distant. \\
\hline $22 / 2100$ & $63^{\circ} 37 \cdot 1^{\prime} \mathrm{N}$ & $08^{\circ} 05 \cdot 6^{\prime} \mathrm{W}$ & $82 \cdot 6^{\prime} /$ Eysturoy & 9 & 0 & 9 & Distant. \\
\hline $22 / 2200$ & $63^{\circ} 43 \cdot 1^{\prime} \mathrm{N}$ & $08^{\circ} 08 \cdot 9^{\prime} \mathrm{W}$ & $89 \cdot 2^{\prime} /$ Eysturoy & 7 & 0 & 7 & Distant. \\
\hline $22 / 2300$ & $63^{\circ} 49 \cdot 3^{\prime} \mathrm{N}$ & $08^{\circ} 11 \cdot 5^{\prime} \mathrm{W}$ & $95 \cdot 3^{\prime} /$ Eysturoy & 2 & 0 & 2 & Distant. \\
\hline $23 / 0000$ & $63^{\circ} 55 \cdot 6^{\prime} \mathrm{N}$ & $08^{\circ} 13 \cdot 9^{\prime} \mathrm{W}$ & $102 \cdot 0^{\prime} /$ Eysturoy & 0 & 4 & 4 & Distant gulls. \\
\hline $23 / 0100$ & $64^{\circ} 01 \cdot 4^{\prime} \mathrm{N}$ & $08^{\circ} 17 \cdot 0^{\prime} \mathrm{W}$ & $107 \cdot 3^{\prime} /$ Eysturoy & 1 & 0 & 1 & \\
\hline $23 / 0200$ & $64^{\circ} 05 \cdot 4^{\prime} \mathrm{N}$ & $08^{\circ} 20 \cdot 7^{\prime} \mathrm{W}$ & $111 \cdot 6^{\prime} /$ Eysturoy & 3 & 0 & 3 & \\
\hline $23 / 0300$ & $64^{\circ} 08 \cdot 9^{\prime} \mathrm{N}$ & $08^{\circ} 23 \cdot 3^{\prime} \mathrm{W}$ & $115 \cdot 5^{\prime} /$ Eysturoy & 1 & 0 & 1 & \\
\hline $23 / 0400$ & $64^{\circ} 12 \cdot 3^{\prime} \mathrm{N}$ & $08^{\circ} 27 \cdot 9^{\prime} \mathrm{W}$ & $119 \cdot 3^{\prime} /$ Eysturoy & 2 & 0 & 2 & \\
\hline $23 / 0500$ & $64^{\circ} 14 \cdot 7^{\prime} \mathrm{N}$ & $08^{\circ} 32 \cdot 6^{\prime} \mathrm{W}$ & $122 \cdot 5^{\prime} /$ Eysturoy & 3 & 0 & 3 & \\
\hline $23 / 0600$ & $64^{\circ} 18 \cdot 1^{\prime} \mathrm{N}$ & $08^{\circ} 37 \cdot 7^{\prime} \mathrm{W}$ & $125 \cdot 7^{\prime} /$ Eysturoy & 2 & 0 & 2 & \\
\hline
\end{tabular}


Table A1 (Cont.)

\begin{tabular}{|c|c|c|c|c|c|c|c|}
\hline $\begin{array}{l}\text { June } 2012 \\
\text { Date/Time } \\
\text { (BST) }\end{array}$ & Latitude & Longitude & $\begin{array}{l}\text { Distance from } \\
\text { Nearest Land } \\
(\mathrm{nm}) / \text { Identity }\end{array}$ & Fulmars & $\begin{array}{l}\text { Other } \\
\text { Birds }\end{array}$ & $\begin{array}{l}\text { Total } \\
\text { Birds }\end{array}$ & $\begin{array}{c}\text { Relevant } \\
\text { Observations }\end{array}$ \\
\hline $23 / 0700$ & $64^{\circ} 20 \cdot 5^{\prime} \mathrm{N}$ & $08^{\circ} 43 \cdot 4^{\prime} \mathrm{W}$ & 129·4'/Eysturoy & 1 & 0 & 1 & \\
\hline $23 / 1400$ & $64^{\circ} 45 \cdot 6^{\prime} \mathrm{N}$ & $09^{\circ} 19 \cdot 3^{\prime} \mathrm{W}$ & $107 \cdot 8^{\prime} /$ Iceland & 2 & 0 & 2 & \\
\hline $23 / 1600$ & $64^{\circ} 55 \cdot 2^{\prime} \mathrm{N}$ & $09^{\circ} 34 \cdot 0 \mathrm{~W}$ & $100 \cdot 1^{\prime} /$ Iceland & 2 & 0 & 2 & \\
\hline $23 / 2300$ & $65^{\circ} 18 \cdot 1^{\prime} \mathrm{N}$ & $10^{\circ} 22 \cdot 7^{\prime} \mathrm{W}$ & $82 \cdot 3^{\prime} /$ Iceland & 1 & 0 & 1 & \\
\hline $24 / 1100$ & $65^{\circ} 43 \cdot 0^{\prime} \mathrm{N}$ & $11^{\circ} 09 \cdot 3^{\prime} \mathrm{W}$ & $62 \cdot 8^{\prime} /$ Iceland & 13 & 0 & 13 & \\
\hline $24 / 1300$ & $65^{\circ} 48 \cdot 9^{\prime} \mathrm{N}$ & $11^{\circ} 08 \cdot 2^{\prime} \mathrm{W}$ & $64 \cdot 3^{\prime} /$ Iceland & 6 & 0 & 6 & Unusual clouds to NW. \\
\hline $24 / 1400$ & $65^{\circ} 52 \cdot 9^{\prime} \mathrm{N}$ & $11^{\circ} 07 \cdot 0^{\prime} \mathrm{W}$ & $65 \cdot 8^{\prime} /$ Iceland & 7 & 0 & 7 & \\
\hline $24 / 1500$ & $65^{\circ} 54 \cdot 8^{\prime} \mathrm{N}$ & $11^{\circ} 09 \cdot 8^{\prime} \mathrm{W}$ & $65 \cdot 5^{\prime} /$ Iceland & 5 & 0 & 5 & \\
\hline $24 / 1800$ & $65^{\circ} 59 \cdot 1^{\prime} \mathrm{N}$ & $11^{\circ} 26 \cdot 8^{\prime} \mathrm{W}$ & $60 \cdot 6^{\prime} /$ Iceland & 9 & 0 & 9 & \\
\hline $24 / 1900$ & $66^{\circ} 01 \cdot 9^{\prime} \mathrm{N}$ & $11^{\circ} 32 \cdot 2^{\prime} \mathrm{W}$ & $60 \cdot 7^{\prime} /$ Iceland & 5 & 0 & 5 & \\
\hline $24 / 2000$ & $66^{\circ} 06 \cdot 3^{\prime} \mathrm{N}$ & $11^{\circ} 38 \cdot 8^{\prime} \mathrm{W}$ & $60 \cdot 7^{\prime} /$ Iceland & 11 & 0 & 11 & White unidentified sputum-like substance in water. \\
\hline $24 / 2300$ & $66^{\circ} 18 \cdot 1^{\prime} \mathrm{N}$ & $11^{\circ} 45 \cdot 2^{\prime} \mathrm{W}$ & $66 \cdot 2^{\prime} /$ Iceland & 3 & 2 & 5 & Gull plus tern, which tried to land on mast several times. \\
\hline $25 / 0000$ & $66^{\circ} 21 \cdot 8^{\prime} \mathrm{N}$ & $11^{\circ} 44 \cdot 1^{\prime} \mathrm{W}$ & $68 \cdot 7^{\prime} /$ Iceland & 2 & 1 & 3 & Arctic Skua tried to land on mast. \\
\hline $25 / 0100$ & $66^{\circ} 24 \cdot 9^{\prime} \mathrm{N}$ & $11^{\circ} 42 \cdot 7^{\prime} \mathrm{W}$ & $67 \cdot 3^{\prime} /$ Iceland & 1 & 1 & 2 & Gull. \\
\hline $25 / 0700$ & $66^{\circ} 38 \cdot 8^{\prime} \mathrm{N}$ & $12^{\circ} 10 \cdot 1^{\prime} \mathrm{W}$ & $59 \cdot 5^{\prime} /$ Iceland & 2 & 3 & 5 & Gulls. \\
\hline $25 / 1000$ & $66^{\circ} 40 \cdot 9^{\prime} \mathrm{N}$ & $12^{\circ} 31 \cdot 9^{\prime} \mathrm{W}$ & $52 \cdot 5^{\prime} /$ Iceland & 8 & 0 & 8 & Pilot Whale. 2 Skuas. \\
\hline $25 / 1600$ & $66^{\circ} 44 \cdot 8^{\prime} \mathrm{N}$ & $13^{\circ} 23 \cdot 7^{\prime} \mathrm{W}$ & $35 \cdot 3$ '/Iceland & 10 & 1 & 11 & Distant. Flotsam: carrier bag. \\
\hline $25 / 1700$ & $66^{\circ} 45 \cdot 4^{\prime} \mathrm{N}$ & $13^{\circ} 34 \cdot 7^{\prime} \mathrm{W}$ & $32 \cdot 8^{\prime} /$ Iceland & 11 & 300 & 311 & Puffins. Seaweed. \\
\hline $25 / 1800$ & $66^{\circ} 47 \cdot 2^{\prime} \mathrm{N}$ & $13^{\circ} 44 \cdot 1^{\prime} \mathrm{W}$ & $32 \cdot 2^{\prime} /$ Iceland & 7 & 21 & 28 & 18 Puffins, 2 Kittiwakes, plus 1 unidentified. \\
\hline $25 / 1900$ & $66^{\circ} 47 \cdot 8^{\prime} \mathrm{N}$ & $13^{\circ} 54 \cdot 4^{\prime} \mathrm{W}$ & $29 \cdot 1^{\prime} /$ Iceland & 3 & 6 & 9 & 5 Puffins, 1 Gull, 12 Jellyfish. \\
\hline $25 / 2000$ & $66^{\circ} 48 \cdot 5^{\prime} \mathrm{N}$ & $14^{\circ} 05 \cdot 2^{\prime} \mathrm{W}$ & $28 \cdot 7^{\prime} /$ Iceland & 3 & 10 & 13 & Puffins. Driftwood. Seaweed. \\
\hline $25 / 2100$ & $66^{\circ} 49 \cdot 0^{\prime} \mathrm{N}$ & $14^{\circ} 12 \cdot 2^{\prime} \mathrm{W}$ & $27 \cdot 9^{\prime} /$ Iceland & 9 & 3 & 12 & Land sighted. Seaweed. Jellyfish. \\
\hline $25 / 2200$ & $66^{\circ} 49 \cdot 8^{\prime} \mathrm{N}$ & $14^{\circ} 23 \cdot 0^{\prime} \mathrm{W}$ & $27 \cdot 8^{\prime} /$ Iceland & 5 & 0 & 5 & \\
\hline $25 / 2300$ & $66^{\circ} 50 \cdot 3^{\prime} \mathrm{N}$ & $14^{\circ} 33 \cdot 9^{\prime} \mathrm{W}$ & $28 \cdot 1^{\prime} /$ Iceland & 3 & 2 & 5 & Skuas. \\
\hline $26 / 0000$ & $66^{\circ} 51 \cdot 0^{\prime} \mathrm{N}$ & $14^{\circ} 45 \cdot 0^{\prime} \mathrm{W}$ & $28 \cdot 5^{\prime} /$ Iceland & 0 & 4 & 4 & Puffins. \\
\hline $26 / 0100$ & $66^{\circ} 51 \cdot 3^{\prime} \mathrm{N}$ & $14^{\circ} 54 \cdot 7^{\prime} \mathrm{W}$ & $28 \cdot 5^{\prime} /$ Iceland & 0 & 5 & 5 & Puffins. \\
\hline $26 / 0200$ & $66^{\circ} 50 \cdot 8^{\prime} \mathrm{N}$ & $15^{\circ} 05 \cdot 8^{\prime} \mathrm{W}$ & $28 \cdot 7^{\prime} /$ Iceland & 2 & 7 & 9 & Puffins. Pilot Whales. \\
\hline $26 / 0600$ & $66^{\circ} 50 \cdot 7^{\prime} \mathrm{N}$ & $15^{\circ} 37 \cdot 9^{\prime} \mathrm{W}$ & $21 \cdot 0^{\prime} /$ Iceland & 12 & 0 & 12 & Lion's Mane Jellyfish. Pilot Whales. \\
\hline $26 / 0800$ & $66^{\circ} 51 \cdot 7^{\prime} \mathrm{N}$ & $16^{\circ} 03 \cdot 2^{\prime} \mathrm{W}$ & $19 \cdot 8^{\prime} /$ Iceland & & & & In mist. Seaweed. Jellyfish. Rubbish. \\
\hline $26 / 0900$ & $66^{\circ} 52 \cdot 2^{\prime} \mathrm{N}$ & $16^{\circ} 15 \cdot 6^{\prime} \mathrm{W}$ & $20 \cdot 6^{\prime} /$ Iceland & 5 & 8 & 13 & Puffins. Driftwood. \\
\hline $26 / 1200$ & $66^{\circ} 53 \cdot 1^{\prime} \mathrm{N}$ & $16^{\circ} 53 \cdot 0^{\prime} \mathrm{W}$ & $24 \cdot 3^{\prime} /$ Iceland & 4 & 1 & 5 & Guillemot. \\
\hline
\end{tabular}


Table A1 (Cont.)

\begin{tabular}{|c|c|c|c|c|c|c|c|}
\hline $\begin{array}{l}\text { June } 2012 \\
\text { Date/Time } \\
\text { (BST) }\end{array}$ & Latitude & Longitude & $\begin{array}{l}\text { Distance from } \\
\text { Nearest Land } \\
(\mathrm{nm}) / \text { Identity }\end{array}$ & Fulmars & $\begin{array}{l}\text { Other } \\
\text { Birds }\end{array}$ & $\begin{array}{l}\text { Total } \\
\text { Birds }\end{array}$ & $\begin{array}{c}\text { Relevant } \\
\text { Observations }\end{array}$ \\
\hline $26 / 1400$ & $66^{\circ} 56 \cdot 4^{\prime} \mathrm{N}$ & $17^{\circ} 12 \cdot 7^{\prime} \mathrm{W}$ & & & & & $\begin{array}{l}17 \text { Fulmars congregated around } \\
\text { the boat, when we stopped } \\
\text { motoring for lunch. }\end{array}$ \\
\hline $26 / 1600$ & $67^{\circ} 01 \cdot 2^{\prime} \mathrm{N}$ & $17^{\circ} 12 \cdot 2^{\prime} \mathrm{W}$ & $33 \cdot 7^{\prime} /$ Grimsey & 2 & 5 & 7 & Puffins. \\
\hline $26 / 1800$ & $66^{\circ} 58 \cdot 3^{\prime} \mathrm{N}$ & $17^{\circ} 34 \cdot 4^{\prime} \mathrm{W}$ & $26 \cdot 9^{\prime} /$ Grimsey & 4 & 7 & 11 & 5 Puffins, 2 Gulls. Pilot Whales \\
\hline $26 / 1900$ & $66^{\circ} 56 \cdot 6^{\prime} \mathrm{N}$ & $17^{\circ} 45 \cdot 4^{\prime} \mathrm{W}$ & $24 \cdot 0^{\prime} /$ Grimsey & 2 & 4 & 6 & Puffins. Pilot Whales. \\
\hline $26 / 2000$ & $66^{\circ} 55 \cdot 1^{\prime} \mathrm{N}$ & $17^{\circ} 55 \cdot 8^{\prime} \mathrm{W}$ & $21 \cdot 7^{\prime} /$ Grimsey & 1 & 4 & 5 & 2 Kittiwakes, 1 Puffin, 1 Skua. \\
\hline $26 / 2100$ & $66^{\circ} 53 \cdot 2^{\prime} \mathrm{N}$ & $18^{\circ} 06 \cdot 7^{\prime} \mathrm{W}$ & $19 \cdot 7^{\prime} /$ Grimsey & 3 & 22 & 25 & $\begin{array}{l}3 \text { Guillemots, } 18 \text { Puffins, } 1 \text { Kittiwake. } \\
\text { Grimsey sighted. }\end{array}$ \\
\hline $26 / 2200$ & $66^{\circ} 50 \cdot 7^{\prime} \mathrm{N}$ & $18^{\circ} 17 \cdot 8^{\prime} \mathrm{W}$ & $18 \cdot 3 ' /$ Grimsey & 4 & 6 & 10 & $\begin{array}{l}2 \text { Gulls, } 4 \text { Puffins. Boat visual and radar, } \\
\text { then disappeared on both. }\end{array}$ \\
\hline $27 / 0000$ & $66^{\circ} 46 \cdot 3^{\prime} \mathrm{N}$ & $18^{\circ} 38 \cdot 7^{\prime} \mathrm{W}$ & $19 \cdot 5^{\prime} /$ Grimsey & 6 & 4 & 10 & 3 Puffins, 1 Gull. \\
\hline $27 / 0100$ & $66^{\circ} 43 \cdot 8^{\prime} \mathrm{N}$ & $18^{\circ} 44 \cdot 9^{\prime} \mathrm{W}$ & $20 \cdot 1^{\prime} /$ Grimsey & 4 & 3 & 7 & 1 Gull, 2 Guillemots. Fishing boat. \\
\hline $27 / 0200$ & $66^{\circ} 46 \cdot 9^{\prime} \mathrm{N}$ & $18^{\circ} 51 \cdot 4^{\prime} \mathrm{W}$ & $24 \cdot 1^{\prime} /$ Grimsey & 3 & 1 & 4 & Puffin. Middle of the night, but still easy to read. \\
\hline $27 / 0400$ & $66^{\circ} 50 \cdot 0^{\prime} \mathrm{N}$ & $19^{\circ} 02 \cdot 2^{\prime} \mathrm{W}$ & $29 \cdot 3^{\prime} /$ Grimsey & 2 & 2 & 4 & Guillemots. Dolphins playing off the bow wave. \\
\hline $27 / 0800$ & $66^{\circ} 47 \cdot 0^{\prime} \mathrm{N}$ & $19^{\circ} 35 \cdot 1^{\prime} \mathrm{W}$ & $39 \cdot 5^{\prime} /$ Iceland & 2 & 7 & 9 & 1 Gull, 3 Puffins, 3 Guillemots. Seaweed. \\
\hline $27 / 1200$ & $66^{\circ} 49 \cdot 0^{\prime} \mathrm{N}$ & $20^{\circ} 13 \cdot 8^{\prime} \mathrm{W}$ & $42 \cdot 4^{\prime} /$ Iceland & 4 & 0 & 4 & Rubbish. \\
\hline $27 / 1500$ & $66^{\circ} 51 \cdot 5^{\prime} \mathrm{N}$ & $20^{\circ} 54 \cdot 1^{\prime} \mathrm{W}$ & $43 \cdot 8^{\prime} /$ Iceland & 1 & 2 & 3 & Puffins. Water colour change. \\
\hline $27 / 1600$ & $66^{\circ} 51 \cdot 1^{\prime} \mathrm{N}$ & $21^{\circ} 07 \cdot 5^{\prime} \mathrm{W}$ & $39 \cdot 4^{\prime} /$ Iceland & 10 & 4 & 14 & $\begin{array}{l}2 \text { Puffins, } 2 \text { Guillemots. Two } \\
\text { distinct water colours. }\end{array}$ \\
\hline $27 / 1700$ & $66^{\circ} 50 \cdot 2^{\prime} \mathrm{N}$ & $21^{\circ} 19 \cdot 0^{\prime} \mathrm{W}$ & $35 \cdot 2^{\prime} /$ Iceland & 3 & 20 & 23 & Puffins. Land visible. \\
\hline $27 / 1800$ & $66^{\circ} 48 \cdot 2^{\prime} \mathrm{N}$ & $21^{\circ} 29 \cdot 2^{\prime} \mathrm{W}$ & $30 \cdot 8^{\prime} /$ Iceland & 20 & 20 & 40 & $\begin{array}{l}\text { Kittiwakes and Puffins. Ratio estimated. } \\
\text { Rubbish. Seaweed. North wind has bite to it. }\end{array}$ \\
\hline $27 / 1900$ & $66^{\circ} 46 \cdot 8^{\prime} \mathrm{N}$ & $21^{\circ} 39 \cdot 2^{\prime} \mathrm{W}$ & $28 \cdot 1^{\prime} /$ Iceland & 25 & 25 & 50 & Kittiwakes and Puffins. Ratio estimated. Rubbish. \\
\hline $27 / 2000$ & $66^{\circ} 45 \cdot 9^{\prime} \mathrm{N}$ & $21^{\circ} 49 \cdot 3^{\prime} \mathrm{W}$ & $23 \cdot 8^{\prime} /$ Iceland & 5 & 33 & 38 & 31 Puffins, 2 Gulls. Water colour changed back. \\
\hline $27 / 2100$ & $66^{\circ} 45 \cdot 5^{\prime} \mathrm{N}$ & $21^{\circ} 58 \cdot 0^{\prime} \mathrm{W}$ & $21 \cdot 4^{\prime} /$ Iceland & 6 & 42 & 48 & 37 Puffins, 2 Gulls, 3 Guillemots. \\
\hline $27 / 2200$ & $66^{\circ} 43 \cdot 5^{\prime} \mathrm{N}$ & $22^{\circ} 04 \cdot 4^{\prime} \mathrm{W}$ & $18 \cdot 1^{\prime} /$ Iceland & 4 & 10 & 14 & 3 Gulls, 7 Puffins. \\
\hline $28 / 0000$ & $66^{\circ} 41 \cdot 1^{\prime} \mathrm{N}$ & $22^{\circ} 13 \cdot 1^{\prime} \mathrm{W}$ & $14 \cdot 3^{\prime} /$ Iceland & 8 & 2 & 10 & Gulls. \\
\hline $28 / 0200$ & $66^{\circ} 36 \cdot 2^{\prime} \mathrm{N}$ & $22^{\circ} 31 \cdot 8^{\prime} \mathrm{W}$ & $8 \cdot 4^{\prime} /$ Iceland & 0 & 42 & 42 & 40 Puffins, 2 Kittiwakes. \\
\hline $28 / 0300$ & $66^{\circ} 35 \cdot 0^{\prime} \mathrm{N}$ & $22^{\circ} 46 \cdot 0^{\prime} \mathrm{W}$ & $7 \cdot 6^{\prime} /$ Iceland & 7 & 16 & 23 & 14 Puffins, 2 Gulls. \\
\hline $28 / 0400$ & $66^{\circ} 32 \cdot 9^{\prime} \mathrm{N}$ & $22^{\circ} 57 \cdot 6^{\prime} \mathrm{W}$ & $5 \cdot 1^{\prime} /$ Iceland & 8 & 1 & 9 & Gull. \\
\hline
\end{tabular}


Table A1 (Cont.)

\begin{tabular}{|c|c|c|c|c|c|c|c|}
\hline $\begin{array}{l}\text { June } 2012 \\
\text { Date/Time } \\
\text { (BST) }\end{array}$ & Latitude & Longitude & $\begin{array}{l}\text { Distance from } \\
\text { Nearest Land } \\
(\mathrm{nm}) / \text { Identity }\end{array}$ & Fulmars & $\begin{array}{l}\text { Other } \\
\text { Birds }\end{array}$ & $\begin{array}{l}\text { Total } \\
\text { Birds }\end{array}$ & $\begin{array}{c}\text { Relevant } \\
\text { Observations }\end{array}$ \\
\hline $28 / 0500$ & $66^{\circ} 30 \cdot 4^{\prime} \mathrm{N}$ & $23^{\circ} 05 \cdot 9^{\prime} \mathrm{W}$ & $4 \cdot 4^{\prime} /$ Iceland & 5 & 6 & 11 & 1 Gull, 5 Puffins. \\
\hline $28 / 0600$ & $66^{\circ} 27 \cdot 4^{\prime} \mathrm{N}$ & $23^{\circ} 09 \cdot 4^{\prime} \mathrm{W}$ & $1 \cdot 6^{\prime} /$ Iceland & 6 & 2 & 8 & 3 boats visible. \\
\hline $28 / 0700$ & $66^{\circ} 24 \cdot 5^{\prime} \mathrm{N}$ & $23^{\circ} 12 \cdot 4^{\prime} \mathrm{W}$ & $2 \cdot 1^{\prime} /$ Iceland & 6 & 21 & 27 & 20 Puffins, 1 unidentified. \\
\hline $28 / 0800$ & $66^{\circ} 20 \cdot 8^{\prime} \mathrm{N}$ & $23^{\circ} 13 \cdot 9^{\prime} \mathrm{W}$ & $0 \cdot 9^{\prime} /$ Iceland & 10 & 70 & 80 & Mostly Puffins, numbers and ratio estimated. \\
\hline $28 / 0900$ & $66^{\circ} 17 \cdot 7^{\prime} \mathrm{N}$ & $23^{\circ} 04 \cdot 0^{\prime} \mathrm{W}$ & $0 \cdot 7^{\prime} /$ Iceland & 20 & 30 & 50 & Mostly Puffins, numbers and ratio estimated. \\
\hline $28 / 1300$ & & & & & & & Entering uncharted waters. \\
\hline
\end{tabular}

